\title{
Management of retained products of conception with marked vascularity
}

\author{
Belirgin damarlanması olan döllenme ürünü kalıntılarına yaklaşım
}

\author{
Veena Aseeja \\ Department of Gynecology and Obstetrics, MMIMSR, Mullana, India
}

\section{Abstract}

To discuss the management options of retained products of conception (RPOC) with increased vascularity where simple dilatation and curettage may lead to life threatening haemorrhage and endanger the life of the patient. We present a series of three cases that had RPOC with hyper vascularity and were managed with different approaches. A brief review of management options is discussed. Out of three cases of RPOC with hyper vascularity, two cases underwent hysterectomy and one case was managed with methotrexate. From our study and review of literature, we conclude that evaluation of vascularity in all cases of RPOC is mandatory prior to Dilatation\&Curettage in order to avoid the dreaded complication of massive haemorrhage.

(J Turkish-German Gynecol Assoc 2012; 13: 212-4)

Key words: Retained products of conception, increased vascularity, Doppler study, management options

Received: 14 February, 2012

Accepted: 20 April, 2012
Özet

Basit dilatasyon ve küretajın yaşamı tehdit eden hemorajiye yol açabildiği ve hastanın yaşamını tehikeye attığı artmış damarlanması olan döllenme ürünü kalıntılarının (retained products of conception; RPOC) tedavi seçeneklerini tartışmak. Aşırı damarlanmalı RPOC'u olan ve farklı yaklaşımlarla tedavi edilmiş üç olguluk bir seriyi sunmaktayız. Tedavi seçeneklerinin kısa bir değerlendirilmesi tartışılmaktadır. Aşırı damarlanması olan üç RPOC olgusunun ikisine histerektomi yapılmış ve bir olgu metotreksat ile tedavi edilmiştir. Kendi çalışmamız ve literatürün gözden geçirilmesi ile şu sonuca ulaştık: korkulan komplikasyon olan massif hemorajiden sakınmak için Dilatasyon ve Küretajdan önce bütün RPOC olgularında damarlanmanın değerlendirilmesi zorunludur. (J Turkish-German Gynecol Assoc 2012; 13: 212-4)

Anahtar kelimeler: Döllenme ürünü kalıntıları, artmış damarlanma, doppler çalışması, tedavi seçenekleri

Geliş Tarihi: 14 Şubat 2012

Kabul Tarihi: 20 Nisan 2012

\section{Introduction}

Various medical and surgical methods have been employed in the treatment of retained products of conception (RPOC). Amongst the surgical methods the universally accepted technique is simple dilatation and curettage. However, it is estimated that nearly $20 \%$ of RPOC's have increased vascularity and in such cases simple dilatation and curettage (D\&C) may lead to massive haemorrhage (1).

Various causes of increased vascularity of RPOC's include arteriovenous malformations, placental polyp and excessive myometrial invasion by the trophoblasts. Due to excessive trophoblastic invasion of myometrium, the physiological myometrial arteriovenous shunting in the placental bed persists, leading to prominent vascularity. We report a series of three cases of hyper vascular RPOC's and the different ways in which they were managed. We aimed to report these cases because as a routine, it is not the practice to do a Doppler study in cases with RPOCs. It was only when patients started bleeding heavily during the $\mathrm{D} \& \mathrm{C}$ procedure that arteriovenous malformations were suspected and a Doppler ultrasound was done. Evaluation of blood supply to RPOC with colour Doppler ultrasonography prior to $\mathrm{D} \& \mathrm{C}$ may prevent the dreaded complications of massive haemorrhage.

\section{Case Reports}

\section{Case 1}

A 39 year-old female, P3L2A1, presented to us with recurrent episodes of bleeding per vagina after medical termination of pregnancy (MTP) at 11 weeks of pregnancy. Post MTP ultrasonography findings were suggestive of retained products of conception. She had D\&C twice, but bleeding persisted, for which she received two doses of methotrexate Injection. $\beta$-hcg levels were not done prior to admission to our hospital. Her last child was 12 yrs old, delivered by caesarean section. At the time of admission, vital signs were stable, she was not bleeding, and mild pallor was present. On vaginal examination the external os was closed. The uterus was 6-8 weeks pregnant uterus size and bilateral fornices were free. Her hemoglobin was $9.4 \% \mathrm{gm}$, and coagulation profile was within normal limits. Ultrasonography and Colour Doppler showed a heterogeneous mass $2.5 \mathrm{~cm} 2 \mathrm{~cm}$ size with prominent vessels in the myometrium suggestive of either retained products of conception with AV malformations or Invasive mole (Figure 1 and 2). $\beta$-hcg levels were $22.3 \mathrm{miu} / \mathrm{ml}$. D \&C was attempted but she started bleeding profusely and the procedure was abandoned, and bleeding stopped within five minutes. She received two units of blood transfusion. In view of recurrent 


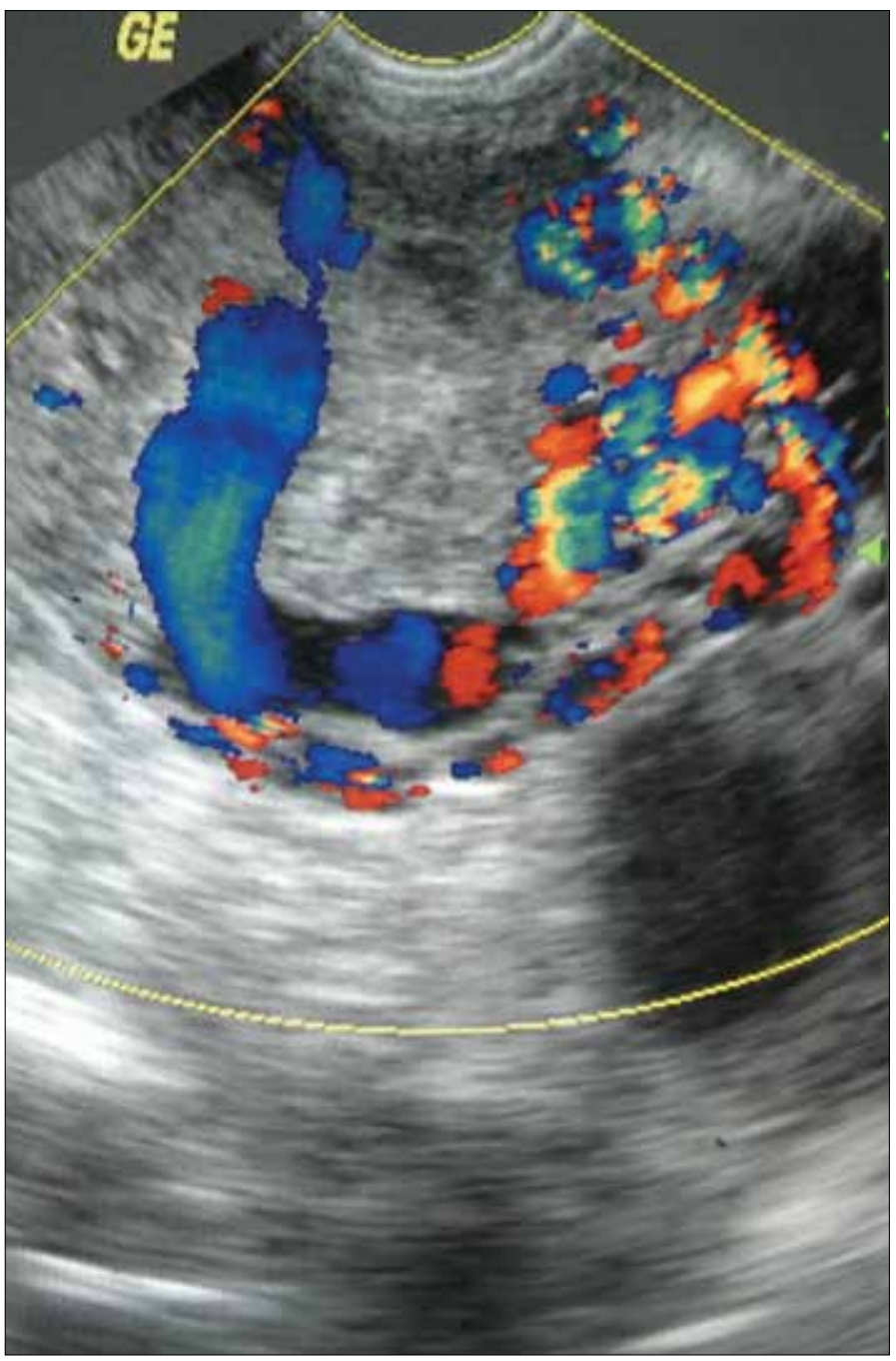

Figure 1. Showing RPOC with AV Malformation

bleeding and doubtful diagnosis of retained products of conceptions with Arteriovenous malformations or invasive mole or possibility of rare persistent trophoblastic tumor, the decision for hysterectomy was taken. Intra-operatively there was leash of vessels on the right side and anterior surface of uterus in the isthmic region. She had excessive bleeding during surgery and received three units of blood. On cut section the uterus showed a mass about $3 \times 3 \mathrm{~cm}$ in size with dilated vessel channels in the isthmocervical area. Histopathological report came out as products of conception. Post operative period was uneventful.

\section{Case 2}

A forty year-old Para 4 with 4 live issues and one abortion presented to our outpatient department with history of recurrent episodes of bleeding per vaginum for the previous three months with no preceding history of amenorrhea. She had had four caesarean sections. On admission her vital signs were stable and bleeding per vagina was present. Urine pregnancy test was weakly positive. Her $\mathrm{Hb}$ was $5 \% \mathrm{gm}$, coagulation profile was within normal limits. Per speculum examination showed a normal cervix and vagina with bleeding from the external cervical os. Per vaginal

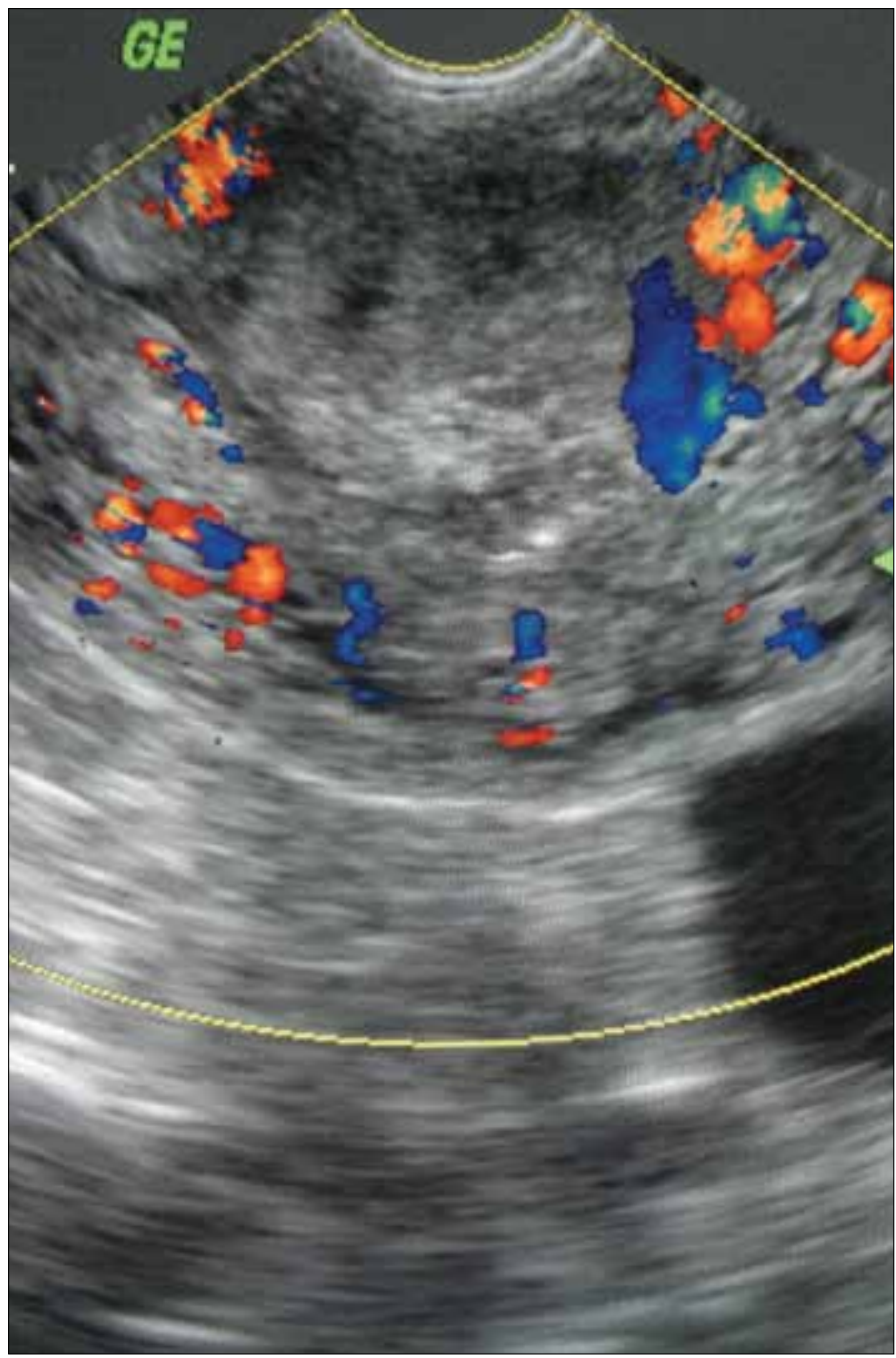

Figure 2. Showing RPOC with hypervascularity

examination showed a retroverted uterus, 6-8 weeks size with bilateral fornices free. Ultrasonography showed a mass of size $6 \times 4 \mathrm{~cm}$ in the cervix and lower endometrial cavity and on Doppler flow there was increased vascularity in the mass and surrounding myometrium and cervix. Her $\beta$-hcg levels were 39 $\mathrm{miu} / \mathrm{ml}$. endometrial aspirates was taken and malignancy was ruled out. In view of the mass invading the myometrium and increased vascularity in the mass and myometrium she was taken up for hysterectomy. On cut section of the uterus there was a friable growth in the isthmus and cervix suggestive of retained products of conception. Histopathology examination confirmed the diagnosis of cervical RPOC. Her post operative period was uneventful.

\section{Case 3}

A 25 year-old P2L2 with previous two normal deliveries presented to us with history of amenorrhea two months and bleeding per vagina since the previous week. On examination her vital signs were stable and per vaginal bleeding was present. Per speculum examination showed a normal cervix and bleeding from the external cervical os. Per vaginal examination revealed a 6-8 
weeks size uterus. $\mathrm{Hb}$ was $10 \% \mathrm{gm}$ and all other investigations were within normal limits. Ultrasonography showed a mass of size $2.0 \times 2.5 \mathrm{~cm}$ in the lower uterine segment suggestive of retained products of conception. She was taken up for D\&C but she started bleeding profusely and the procedure had to be abandoned because of heavy bleeding. Bleeding stopped within 10 minutes of abandoning the procedure. Post procedure Doppler ultrasonography showed increased vascularity in the RPOC and the surrounding myometrium. She was planned for conservative management and an injection of methotrexate $1 \mathrm{mg} / \mathrm{kg}$ intramuscular was given. One week after methotrexate injection a repeat Doppler study showed no vascularity in the myometrium and regression of RPOC.

\section{Discussion}

Hyper vascular RPOC's present a clinical challenge because simple dilatation and curettage in such cases may lead to massive haemorrhage necessitating life saving hysterectomy. The risk factor of developing excessive vascularity in RPOC's includes implantation of the embryo in the lower part of the uterus and a history of multiple D\&C's $(2,3)$. Interestingly, in our series, 2 out of the 3 cases gave a history of multiple D\&C and two cases had an embryo implanted in a relatively lower part of the uterus. Since the endometrium is thin and decidual formation tends to be insufficient in the lower part of the uterus, embryo implantation in this part leads to excessive trophoblastic invasion thereby causing increased vascularity. Tomoko et al. (4) in 2011 reported two cases of hypervascular RPOC's. The diagnosis of hypervascularity was confirmed on colour Doppler ultrasonography. Vascularity was reduced with uterine artery embolization followed by $\mathrm{D} \& \mathrm{C}$, while the second case of hypervascular placental polyp was managed conservatively. They concluded that simple D\&C in cases of hypervascular RPOC should be deferred until its vascularity is sufficiently reduced. Arora et al. (5) reported three cases of uterine AV malformations with recurrent vaginal bleeding. One case presented with bleeding three weeks after medical termination of pregnancy. Repeat D\&C was done with the diagnosis of incomplete abortion which led to massive torrential bleeding for which she was transfused three units of blood. With the suspicion of AV malformation, colour Doppler study was done, which con- firmed the diagnosis. Joseph et al. (6) reported a case with a heavy intractable bleeding per vaginum, following dilatation and curettage for an incomplete abortion. A provisional clinical diagnosis of gestational trophoblastic disease was made. After radiological investigations this was diagnosed as uterine Arterio-venous malformation. The patient was treated by uterine artery embolization, because she wanted to preserve fertility. In our series of three cases, in the first case emergency life saving hysterectomy had to be done while in the second case, in view of the patient's age, completed family and assumed risk of excessive bleeding, D\&C was not attempted and she was taken up for elective hysterectomy. The third patient was managed conservatively with methotrexate injection.

\section{Conclusion}

From our experience and review of literature, we conclude that in all cases of RPOC's, vascularity should be evaluated with colour Doppler prior to attempting dilatation and curettage in order to avoid the complications of massive haemorrhage and hysterectomy.

\section{Conflict of interest}

No conflict of interest was declared by the authors.

\section{References}

1. Kamaya A, Petrovitch I, Chen B, Frederick CE, Jeffrey RB. Retained products of conception: spectrum of color Doppler findings. J Ultrasound Med 2009; 28: 1031-41.

2. Ota Y, Watanabe H, Fukasawa I, Tanaka S, Kawatsu T, Oishi A, et al. Placenta accrete/increta: Review of ten cases and a case report. Arch Gynecol Obstet 1999; 263: 69-72. [CrossRef]

3. Wu S, Kocherginsky M, Hibbard JU. Abnormal placentation: twenty one year analysis. Am J Obstet Gynecol 2005; 192: 1458-61. [CrossRef]

4. Kitahara T, Sato Y, Kakui K, Tatsumi K, Fujiwara H, Konishi I. Management of retained products of conception with marked vascularity. J Obstet Gynaecol Res 2011; 37: 458-64. [CrossRef]

5. Renu A, Achla B, Pinkee S, Purba G, Bharti M. Arteriovenous malformations of the uterus. NZMJ 2004; 117: 1-5.

6. Joseph A, Ramalingam D, Rajalakshmi G, Davidson D. A rare case of post-abortal vaginal bleeding,Uterine malformation,managed by arterial embolization. Pushpagiri Medical Journal 2010; 2: 32-5. 